\title{
ПЕРЕЖИВАННЯ ВІЙНИ: КОНФЛІКТНЕ МИСЛЕННЯ І КОНФЛІКТНА ВЗАСМОДІЯ
}

На основі результатів масового опитування проаналізовано причини конфліктів, які виникають у ході взаємодії між цивільними і військовими. Зауважено, що станом на сьогодні в суспільстві укорінилися певні настановлення щодо участі у війні та ролі військових, причому у військових і цивільних ці настановлення можуть збігатися, а можуть і відрізнятися. Виявлено, що конфліктна взаємодія певною мірою зумовлена, з одного боку, настановленнями цивільних, в основі яких лежить позбавлення військових суб'єктності та надлишкова патологізація процесу їхнього повернення до цивільного життя, а 3 другого - конфлікти можуть бути зумовлені настановленнями військових щодо перебільшення агресивного ставлення цивільних до них. Подано результати масового опитування, в ході якого з'ясувалося, що найчастіше такі конфлікти виникають $з$ представниками держави і державних органів, у повсякденному соціальному житті або ж у сфері сімейних стосунків. На основі результатів опитування зроблено висновок, що український контекст конфліктів між військовими і цивільними пов'язаний 3 несформованістю у цивільного населення реальних уявлень про війну, бойові дії та їхній вплив на військовослужбовців; тривалим перебуванням військових у зоні бойових дій; загальним станом соціальної напруженості, спричиненим воєнними діями та соціально-економічною ситуацією в країні; загальними, характерними для всіх людей помилками сприймання та когнітивними викривленнями; завищеним рівнем взаємних очікувань щодо ролі кожної із сторін у суспільному житті та відповідальності за нього; цілеспрямованим формуванням викривлених уявлень як елементом пропаганди та частини гібридної війни тощо. Результати опитування показали, що $\epsilon$ значна кількість громадян, які не мають визначеної думки щодо низки важливих питань. Висловлено припущення, що загальні механізми переживання невизначеності передбачають, на жаль, зростання кількості негативних, агресивних проявів.

Ключові слова: конфлікти, групова взаємодія, насильство, бойове мислення, адаптація ветеранів.

\section{O. Yu. Kukharuk}

\section{THE EXPERIENCE OF WAR: CONFLICT THINKING AND CONFLICT INTERACTION}

Based on the mass survey results there are analyzed the causes of conflicts that arise while civilians-combatants interaction. It is noted that today the certain attitudes are rooted in society towards servicemen's participation in the war and their role in it; moreover, these attitudes can differ and can coincide in combatants and in civilians. It is revealed that conflict interaction caused to some extent, on the one hand, by civilians' attitudes (which are based on the riddance of combatants' subjectivity and excessive pathologization of the process of their return to civil life), on the other hand, conflicts may be caused by combatants' attitudes towards exaggerated 
civilians' aggression against them. The results of the mass social survey are presented, during which it is discovered that such conflicts most often arise within the state representatives and the state bodies, in everyday social life, or in the sphere of family relations. Based on the results of the survey, it is made a conclusion that Ukrainian context of conflicts between combatants and civilians is related to the unconsciousness of civilian population of real ideas about the war; the hostilities and their impact on combatants; the prolonged combatants presence in the area of hostilities; the general state of social tension caused by military actions and socio-economic situation in the country; the general, typical for all human kind perception mistakes and cognitive distortions; the overstated level of mutual expectations about the role of each party in public life and responsibility for it; the purposeful formation of distorted representations as an element of propaganda and part of a hybrid war, etc. The results of the survey showed that there is also a significant number of citizens who are not certain about their attitude to important war-peace issues. It is made an assumption that the general mechanisms of uncertainty feeling, unfortunately, anticipate the increase in quantity of negative, aggressive manifestations. adaptation.

Key words: conflicts, group interaction, hostilities, martial thinking, veterans'

Постановка проблеми. Конфлікти між військовими і цивільними в ході групової взаємодії можуть проявлятися на всіх рівнях суспільного життя. Це можуть бути, наприклад, конфлікти 3 державою та державними органами, конфлікти в повсякденному соціальному житті та побутові сімейні конфлікти. Такі конфлікти справляють значний негативний вплив на соціально-психологічний клімат у суспільстві. Хоч причинами таких конфліктів стають здебільшого реальні проблемні ситуації, за своєю природою ці конфлікти є соціально-психологічними. 3 огляду на це перед соціальними психологами постає завдання вивчення та осмислення їхньої природи і суті як соціально-психологічного явища.

Аналіз останніх досліджень і публікацій. Тема конфліктів між цивільними і військовими в ході групової взаємодії зовсім не нова для людства в цілому і для психологічної науки зокрема. Коли завершуються бойові дії або закінчується війна, їхні учасники повертаються до мирного життя [1]. Разом із поверненням виникає низка специфічних проблем, які зі свого боку можуть спричиняти конфлікти, а в крайньому разі і насильство. Спроби осмислити природу і суть цих конфліктів робилися й робляться як у науковій, так і в художній та позанаукових формах соціально-психологічного мислення. Перші донаукові спроби осмислити такі конфлікти фіксуємо в мистецтві, найчастіше літературі. Найбільш яскраво описують цей конфлікт, як правило, ті письменники, які самі мали досвід участі в бойових діях. Показовим є, наприклад, опис Е. М. Ремарка: “Мені соромно, але водночас мене душить лють. Лють на дядька Карла, який перебільшено голосно заводить розмову про військові позики; злість на цих людей, які хизуються своїми розумними розмовами; злість на весь цей світ, який так незворушно продов- 
жує існувати, поглинутий своїми маленькими, жалюгідними інтересами, немов і не було цих жахливих років, коли ми знали тільки одне: смерть або життя - і нічого більше" [2].

Можемо спостерігати тему конфліктних стосунків між військовими і цивільними у вітчизняних ЗМІ та масовому дискурсі. Звернімося до результатів дослідження, яке провела ГО “Побратими”: “Відповідно до образу військового на фронті, який формується зараз, учасник бойових дій - це герой, який мужньо зі зброєю в руках захищає свою землю. Та чомусь одразу, коли він повертається, виявляється, що йому потрібна допомога: він уже не такий сильний, а раптом стає потенційним алкоголіком, потенційним наркоманом, потенційно може скоїти суїцид” [3]. Отже, у масових уявленнях простежується розщеплення: військовий це герой, а ветеран-атовець - скалічена війною і агресивна людина. Інакше кажучи, у настановленнях суспільства військовий є об'єктом, який наділяється характеристиками агресора або захисника, що певною мірою позбавляє його власної суб'єктності.

Зрозуміло, що вивчають ці проблеми і психологи, зокрема ті, які спеціалізуються на військовій психології. Так, у низці робіт конфлікти розглядають як наслідок пережитого травматичного досвіду, як індикатор порушень психіки військових, що тягне за собою необхідність їх “лікування” та адаптації до “нормального” життя [4]. У цьому контексті проблема адаптації військових до мирного життя висвітлюється найчастіше під кутом зору впливу пережитого досвіду війни і його травматичних наслідків. У психологічній науці ідея комплексного пояснення конфліктів що виникають у ході групової взаємодії військових і цивільних, не належить до популярних. Перевагу віддають посттравматичним розладам, їх лікуванню та адаптації військових [4-6]. А проте пояснювальний потенціал методів соціально-психологічної науки $\epsilon$ цілком достатнім для комплексного дослідження конфліктів, що виникають, і напрацювання ідей щодо їх розв'язання та корекції.

Конфлікти між людьми, що мають досвід війни, і цивільним населенням привертають останнім часом до себе значну увагу. Невирішеними частинами загальної проблеми залишаються питання, що стосуються конфліктного мислення, притаманного представникам цих груп, і конфліктної взаємодії, до якої воно може призводити. Зокрема, детального вивчення потребують передусім соціально-психологічні чинники, що зумовлюють появу конфліктних настановлень і конфліктів.

Мета статті: грунтуючись на даних, отриманих у ході проведеного опитування, з'ясувати соціально-психологічні чинники виникнення конфліктів між цивільними і військовими.

Виклад основного матеріалу дослідження. Нашим завданням було проаналізувати дані, отримані в ході масового опитування, що проводилося в межах проекту “Альтернативи конфліктам і насильству”. 
Для реалізації проекту було створено дослідницьку групу у складі Г. Циганенко (керівник проекту), О. Кухарук, О. Овчар. Група працювала над темою "Подолання соціальних наслідків конфлікту на Донбасі та незаконної анексії Криму за допомогою державних структур в Україні та громадянського суспільства", який виконувала канадська неурядова організація "Stabilization Support Services".

Дослідницька частина проекту поділялася на два етапи: кількісний і якісний. Кількісний етап проводився в період з 12 до 23 листопада 2016 р. Географія - у масштабах України, а саме підконтрольна Україні частина території Донецької та Луганської областей, зона проведення АТО та обласні міста, середні міста, селища і села в областях, де є і де немає пунктів постійної дислокації військових частин. Було опитано 1270 респондентів. Вибірка охоплювала доросле населення віком від 18 років. Половину опитаних становили військові, другу половину цивільні.

Одним із завдань дослідження було виявлення міжгрупових конфліктних настановлень та ставлення цивільного населення і військових до фактів міжгрупових конфліктів. Інтерпретація отриманих результатів проводилася за двомірними розподілами на основі парних порівнянь відмінностей відсотків у підвибірках незалежних змінних та коефіцієнтів статистичного зв'язку фі-квадрат з рівнем значущості 0,05 i вище. Респонденти відбиралися за квотною вибіркою, дизайн вибірки був зумовлений необхідністю опитати достатню для аналізу кількість осіб у різних типах населених пунктів, серед різних вікових категорій респондентів. Статевий розподіл був репрезентативним щодо гендерного розподілу населення України (для цивільних) і гендерного складу Збройних сил України (для військових).

Першим важливим завданням було з'ясувати, чи відомо цивільним і військовим про міжгрупові конфлікти. Результати опитування показали, що цивільні менше знають про випадки конфліктів, ніж військові, але разом з тим рівень поінформованості їх досить високий: 41\% опитаних чули про такі конфлікти від інших (табл. 1).

Таблиия 1

Загальні результати опитування респондентів щодо їхньої поінформованості про конфлікти

\begin{tabular}{|l|c|c|c|}
\hline \multirow{2}{*}{$\begin{array}{c}\text { Чи відомі Вам випадки } \\
\text { конфліктів між військовими і } \\
\text { цивільними? }\end{array}$} & \multicolumn{3}{|c|}{ Групи респондентів } \\
\cline { 2 - 4 } & Військові & Цивільні & Усі опитані \\
\hline Так, знаю особисто & $40^{*}$ & 16 & 28 \\
\hline Так, щось чув від інших & 31 & $41^{*}$ & 36 \\
\hline $\mathrm{Hi}$ & 29 & $43^{*}$ & 36 \\
\hline
\end{tabular}

* Значущі відмінності між групами на рівні 0,05 і вище. 
Натомість для військових ця тема більш знайома: 40\% знають особисто про такі конфлікти, а переважній їх більшості (71\%) відомо про такі конфлікти. Серед цивільних тих, хто певною мірою знає про такі конфлікти, теж чимало (57\%). Отже, майже дві третини військових i понад половину цивільних - це досить високий показник, для того щоб говорити про актуальність таких конфліктів у суспільстві. Статистично значущою $є$ також різниця між обізнаністю цивільних, що мають стосунок до АТО, і тих, хто такого стосунку не має.

Що ж до безпосередніх конфліктних настановлень, то їх вивчення можна провести, проаналізувавши блок питань, що стосуються військового і цивільного світоглядів (табл. 2). Складно при цьому не зауважити певні суперечності в уявленнях циивільних щодо військових. Проаналізувавши та об'єднавши відповіді за темами, можемо зробити такі узагальнення:

- для цивільних військові пов'язані з почуттям захисту і безпеки; $\epsilon$ визнання того, що, незважаючи на різний досвід, ніхто не $є$ гіршим;

- цивільні переважно ігнорують тему війни, думки про війну;

- вони не бажають виправдовуватися щодо своєї ролі цивільного, при цьому в них невизначене ставлення до свідомого уникання служби та небажання за це виправдовуватись;

- значна частина цивільних не визначилася щодо багатьох питань, у тому числі щодо таких, як ставлення до військових як до загрози і нагадування про війну;

- цивільні значно перебільшують негативне ставлення до себе 3 боку військових або мають високий рівень невизначеності щодо цього питання.

Пояснити таку кількість осіб, що не визначилися, можна або й справді внутрішньою невизначеністю, або намаганням респондентів давати більш соціально бажані відповіді (у такому випадку має збільшуватися частка тих, хто підтримує більш різкі конфліктні настановлення). У всякому разі, яке б із пояснень не було справедливим, і внутрішня невизначеність, і прихована підтримка негативних настановлень обидві позиції $є$ потенційно конфліктогенними. Особливо актуальним це стає в контексті питання, чи несуть військові в собі загрозу нагадуванням про війну. Заперечили таке твердження 60\%. На нашу думку, решта, $40 \%$ цивільних, які бачать у військових загрозу або не можуть визначитися щодо свого ставлення до цього, - усе ж таки зависокий показник.

У результаті, оцінюючи ставлення цивільних до військових, маємо набір суперечливих настановлень: військовий, 3 одного боку, асоціюється з відчуттям захищеності і безпеки, а з другого - 3 нагадуванням про війну і про теми, щодо яких у цивільних переважають невизначені чи негативні настановлення. 
Результати опитування респондентів щодо їхнього ставлення до найбільш поширених конфліктів між цивільними і військовими (у\%)

\begin{tabular}{|c|c|c|c|}
\hline Твердження & Ступінь згоди & Військові & Цивільні \\
\hline \multirow{3}{*}{$\begin{array}{l}\text { Військові для мене пов'язані передусім із } \\
\text { захистом від війни та відчуттям безпеки }\end{array}$} & не погоджуюсь & 6 & $11 *$ \\
\hline & не можу визначитись & 10 & $14^{*}$ \\
\hline & погоджуюсь & $84 *$ & 75 \\
\hline \multirow{3}{*}{$\begin{array}{l}\text { Ti, хто не пішов служити, вчинили } \\
\text { правильно }\end{array}$} & не погоджуюсь & 64* & 40 \\
\hline & не можу визначитись & 24 & $36^{*}$ \\
\hline & погоджуюсь & 13 & $24 *$ \\
\hline \multirow{3}{*}{$\begin{array}{l}\text { Це абсолютно нормально - бути готовим } \\
\text { воювати, тільки якщо є безпосередня } \\
\text { загроза твоєму місту чи області }\end{array}$} & не погоджуюсь & $45^{*}$ & 27 \\
\hline & не можу визначитись & 18 & $22 *$ \\
\hline & погоджуюсь & 37 & $51^{*}$ \\
\hline \multirow{3}{*}{$\begin{array}{l}\text { У військових люди, що живуть у мирних } \\
\text { містах, викликають роздратування, зне- } \\
\text { вагу і злість }\end{array}$} & не погоджуюсь & $60 *$ & 50 \\
\hline & не можу визначитись & 25 & 29 \\
\hline & погоджуюсь & 15 & $21^{*}$ \\
\hline \multirow{3}{*}{$\begin{array}{l}\text { Звичайні, цивільні люди дуже мало уваги } \\
\text { приділяють війні, вона для них неваж- } \\
\text { лива }\end{array}$} & не погоджуюсь & 27 & 30 \\
\hline & не можу визначитись & 25 & 23 \\
\hline & погоджуюсь & 48 & 47 \\
\hline \multirow{3}{*}{$\begin{array}{l}\text { Люди, що пройшли війну, і цивільні на } \\
\text { мирній території мають різний світог- } \\
\text { ляд, але це не значить, що хтось із них } \\
\text { гірший }\end{array}$} & не погоджуюсь & $10 *$ & 6 \\
\hline & не можу визначитись & 14 & 16 \\
\hline & погоджуюсь & 76 & 78 \\
\hline \multirow{3}{*}{$\begin{array}{l}\text { Військові є втіленням загрози від війни, } \\
\text { яку вони приносять у мирні міста. }\end{array}$} & не погоджуюсь & $68 *$ & 59 \\
\hline & не можу визначитись & 23 & 26 \\
\hline & погоджуюсь & 9 & $15^{*}$ \\
\hline \multirow{3}{*}{$\begin{array}{l}\text { Держава і суспільство скоро забудуть } \\
\text { військових. Вони залишаться наодинці } \\
\text { зі своїми проблемами }\end{array}$} & не погоджуюсь & $32 *$ & 25 \\
\hline & не можу визначитись & 28 & 27 \\
\hline & погоджуюсь & 40 & $47^{*}$ \\
\hline \multirow{3}{*}{$\begin{array}{l}\text { Цивільні не мають виправдовуватися за } \\
\text { те, що не воюють. У них інші роль і зав- } \\
\text { дання }\end{array}$} & не погоджуюсь & 15 & 12 \\
\hline & не можу визначитись & $27 *$ & 22 \\
\hline & погоджуюсь & 58 & $67 *$ \\
\hline \multirow{3}{*}{$\begin{array}{l}\text { Після повернення з війни для військових } \\
\text { важливо знову стати частиною мирного } \\
\text { світу }\end{array}$} & не погоджуюсь & 6 & 5 \\
\hline & не можу визначитись & 13 & 13 \\
\hline & погоджуюсь & 81 & 83 \\
\hline \multirow{3}{*}{$\begin{array}{l}\text { У роботі військового найголовніше те, } \\
\text { як він робить свою справу, а не його пе- } \\
\text { реконання, ідеологія чи людські якості }\end{array}$} & не погоджуюсь & 35 & 34 \\
\hline & не можу визначитись & 23 & $28^{*}$ \\
\hline & погоджуюсь & 42 & 38 \\
\hline \multirow{3}{*}{$\begin{array}{l}\text { Людям страшно чути про війну, тому } \\
\text { вони уникають думок про неї }\end{array}$} & не погоджуюсь & 14 & 15 \\
\hline & не можу визначитись & $26^{*}$ & 20 \\
\hline & погоджуюсь & 60 & 65 \\
\hline
\end{tabular}

* Значущі відмінності між групами на рівні 0,05 і вище.

Додатковим чинником можна вважати очікування перебільшено негативного ставлення до себе з боку військових або невизначеність щодо цього питання. У підсумку - позитивне ставлення до військових у цивільних поєднується із внутрішньою невизначеністю, наполегливим 
униканням тем, дотичних до війни (і часто пов'язаних із військовими), і перебільшеними очікуваннями негативного ставлення до себе з боку військових. У такому випадку закономірною людською реакцією на невизначеність $є$ тривога і тривожні реакції (у тому числі намагання уникати й агресивно захищатись). Схожими можуть бути й реакції на очікуване негативне ставлення.

Аналізуючи відповіді військових на ці ж питання, бачимо в них більше визначеності щодо певних настановлень. Так, у військових більш чітко виявлена самоасоціація з безпекою і захистом, вищий рівень усвідомлення необхідності захищати країну, до того як з'явиться безпосередня загроза конкретній території проживання. При цьому військові так само, як і цивільні, зауважують, що останні воліють уникати теми війни, але свої негативні почуття вони виявляють значно рідше, ніж цивільні від них цього очікують. Так само, як і цивільні, військові не вважають, що чийсь досвід, військовий чи цивільний, є гіршим, але значно рідше, ніж цивільні, асоціюють себе із загрозою війни. Зате значуще вищим серед військових є частка тих, хто очікує виправдань від цивільних за уникання участі у війні. Спільним у настановленнях військових і цивільних щодо цих питань $є$ досить високий рівень невизначеності. У військових виняток становлять тільки питання, пов'язані з безпосередньою участю у війні.

Отже, навіть за результатами аналізу одного блоку питань, що стосуються ролі військових і цивільних у певних сферах цивільного життя і їхніх взаємовідносин, можна зробити певні висновки. Перш за все бачимо точку дотику: позитивне ставлення до військових як до уособлення гарантій миру і безпеки. Але разом 3 тим простежуємо значний незбіг між настановленнями щодо необхідності участі у війні, ставленням до загрози війни і реакцією на цю загрозу. Додатковим чинником напруженості $\epsilon$, на нашу думку, досить високий рівень невизначеності в обох групах щодо багатьох, у тому числі емоційно заряджених, питань. А беручи до уваги загальні психологічні механізми переживання невизначеності та виявлене в ході опитування очікування негативного ставлення до себе, можемо зробити припущення, що взаємодія буде відбуватися, найімовірніше, в негативному ключі.

Варто зауважити, що перебільшені очікування щодо негативного ставлення $є$ у представників обох груп - і у військових, і в цивільних. Маємо підстави говорити про виразну тенденцію з боку військових применшувати рівень вираженості позитивних почуттів і перебільшувати рівень вираженості негативних (рис. 1). У середовищі цивільних спостерігається аналогічна тенденція (рис. 2). За рейтингом вибір військових і цивільних у цих питаннях збігається, тобто військові досить точно знають, які почуття вони викликають у цивільних, а цивільні досить чітко можуть оцінити, як ставляться військові до них. Найбільш 
помітними є кількісні розбіжності. Хоча почуття вибирають "правильно" обидві групи, кожна 3 них вважає, що інша має щодо неї більш сильні негативні почуття і менш виражені позитивні, ніж це $\epsilon$ насправді. Так, військові переоцінюють те, як часто вони викликають у цивільних роздратування (насправді не так часто), а цивільні значно рідше, ніж це роблять, наприклад, військові щодо них, вибирають “повагу”.

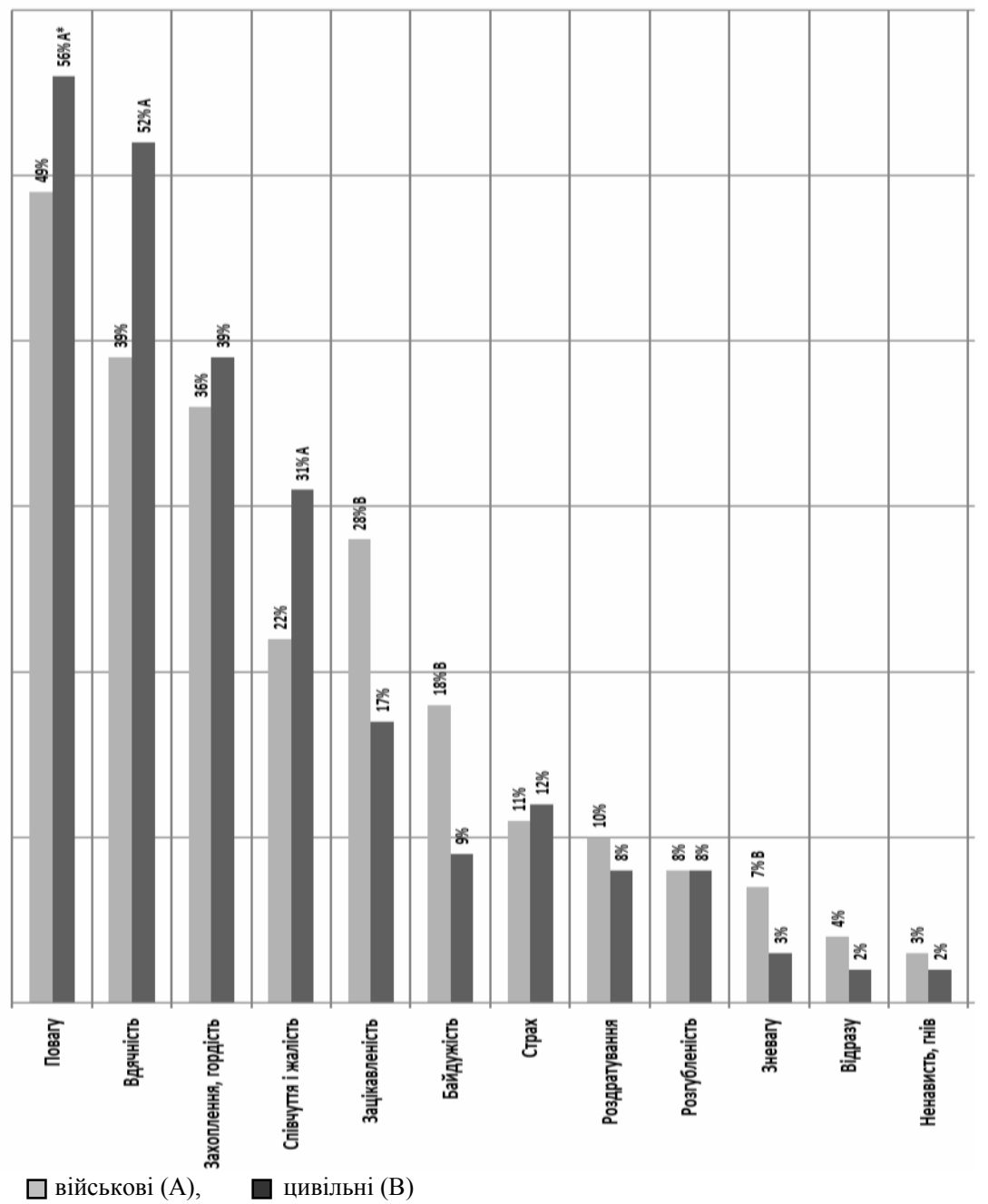

Puc. 1. Результати опитування респондентів щодо того, які почуття військові викликають у цивільних 


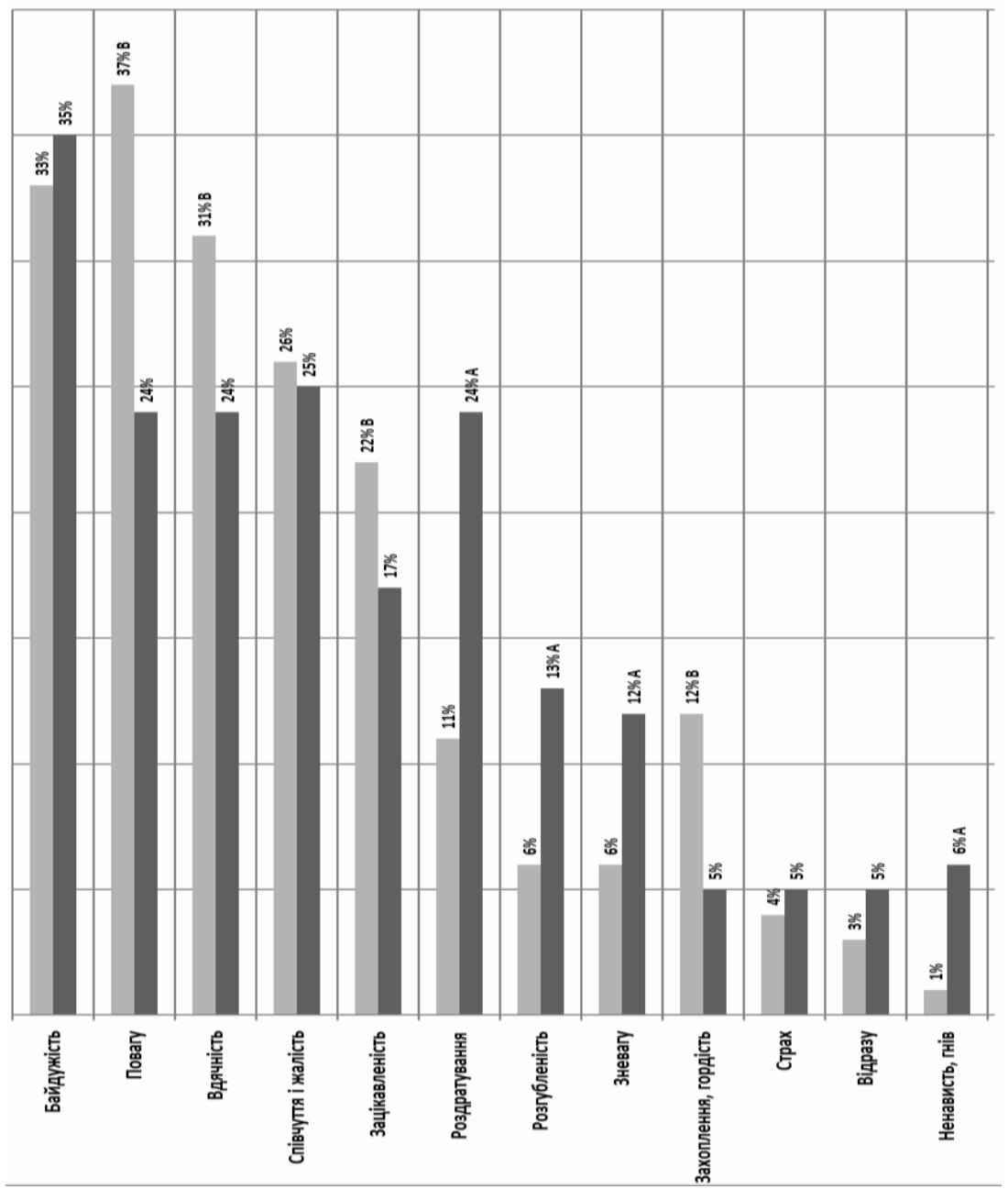

$\square$ військові (А), $\square$ цивільні (В)

Puc. 2. Результати опитування щодо того, які почуття цивільні викликають у військових

Отже, можемо говорити про певні соціально-психологічні особливості взаємосприйняття цивільних і військових:

- позитивне ставлення до ролі військових як до уособлення гарантій безпеки і захисту;

- переважання позитивних почуттів у міжгруповому сприйнятті; 
- негативні очікування, коли йдеться про ставлення представників інших груп до власної групи;

- розбіжність в уявленнях щодо участі у війні, необхідності військової служби;

- велика частка осіб, що не визначилися щодо низки питань, які стосуються війни та участі в ній.

Перелік конфліктних точок дає підстави припустити, що є дві лінії, які можуть провокувати конфлікт: зовнішня (конфлікт сформованих, чітких настановлень) і внутрішня (внутрішній конфлікт і невизначеність, підкріплені негативними очікуваннями). У реальному житті ці лінії часто перетинаються й утворюють індивідуальні комбінації, притаманні кожній людині.

Висновки та перспективи подальших досліджень. Станом на сьогодні в суспільстві укорінилися певні настановлення щодо участі у війні та ролі військових. У військових і цивільних ці настановлення можуть збігатися, а можуть і відрізнятися. Найбільші розбіжності в цих настановленнях стосуються участі у війні. Окрім визначених у результаті опитування настановлень, звертає на себе увагу значна кількість громадян, що наразі не визначилися у своєму ставленні до низки питань. Загальні механізми переживання невизначеності передбачають увиразнення найчастіше негативних, агресивних проявів. При цьому спостерігаються негативні очікування щодо ставлення аутгрупи до інгрупи (водночас із приписуванням собі позитивних почуттів до аутгрупи).

Отримані результати дають змогу розробити певні рекомендації для психологів, які працюють з військовими, щодо уникнення конфліктів у мирному житті. Ці рекомендації мають базуватися на усвідомленні причин та відпрацюванні можливих стратегій поведінки в міжгруповому конфлікті.

Подальші дослідження можуть стосуватися як глибшого вивчення конфліктних настановлень, так і напрацювання інструментів для розв'язання цих конфліктів або запобігання виникненню конфліктних ситуацій.

\section{Список використаних джерел}

1. Vision of Humanity - Global Peace Index and Positive Peace. Vision of Humanity. Взято $3 \mathrm{http}: / / \mathrm{www} . v i s i o n o f h u m a n i t y . o r g / \# p a g e / i n d e x e s / g l o b a l-p e a c e-i n d e x /$ 2016/UKR/OVER.

2. Ремарк, Е. М. (2014). На Західному фронті без змін. Повернення. Три товариші. Харків: Клуб Сімейного Дозвілля.

3. Дачковська, М. (2016). Образ ветерана АТО в медіа: як уникати стерео-

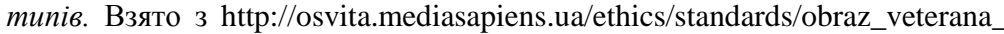
ato_v_media_yak_unikati_stereotipiv.

4. Міністерство оборони України (2016). Начальник Науково-дослідного иентру гуманітарних проблем Збройних Сил Украӥни Назім Агаєв розповів 
про психологічні проблеми військовослужбовців - учасників АТО. Взято $з$ https://goo.gl/r5ZkwV.

5. Summerfield, D. (1996). The Impact of War and Atrocity on Civilian Populations: Basic Principles for NGO Interventions and a Critique of Psychosocial Trauma Projects. London: Overseas Development Institute.

6. Fairbank, J. A., Friedman, M. J., de Jong, J., et al. (2003). Intervention options for society, communities, families, and individuals. In: Green, B. L, Friedman, M. J, de Jong J., et al. (Eds.). Trauma interventions in war and peace: prevention, practice, and policy (pp. 57-72). New York: Kluwer/Plenum.

\section{References}

1. Vision of Humanity - Global Peace Index and Positive Peace. Vision of Humanity. Retrieved from http://www.visionofhumanity.org/\#pag/indexes/global-peaceindex/2016/UKR/OVER.

2. Remark, E. M. (2014). Na Zakhidnomu fronti bez zmin. Povernennia. Try tovaryshi [All Quiet on the Western Front. The Road Back. Three Comrades]. Kharkiv: Klub Simeinoho Dozvillia (ukr).

3. Dachkovska, M. (2016). Obraz veterana ATO v media: yak unykaty stereotypiv [The image of veteran ATO in the media: how to avoid stereotypes]. Retrieved from http://osvita.mediasapiens.ua/ethics/standards/obraz_veterana_ato_v_ media_yak_unikati_stereotipiv (ukr).

4. Ministerstvo oborony Ukrainy (2016). Nachalnyk Naukovo-doslidnoho tsentru humanitarnykh problem Zbroinykh Syl Ukrayiny Nazim Ahayev rozpoviv pro psykholohichni problemy viiskovosluzhbovtsiv - uchasnykiv ATO [Head of the Research Center for Humanitarian Problems of the Armed Forces of Ukraine Nazim Agayev spoke about the psychological problems of soldiers - ATO participants]. Retrieved from https://goo.gl/r5ZkwV (ukr).

5. Summerfield, D. (1996). The Impact of War and Atrocity on Civilian Populations: Basic Principles for NGO Interventions and a Critique of Psychosocial Trauma Projects. London: Overseas Development Institute.

6. Fairbank, J. A., Friedman, M. J., de Jong, J., et al (2003). Intervention options for society, communities, families, and individuals. In: Green, B. L, Friedman, M. J, de Jong J., et al. (Eds). Trauma interventions in war and peace: prevention, practice, and policy (pp. 57-72). New York: Kluwer/Plenum.

(C) Кухарук О. Ю. 